FinalDraft

Article information:

Rostislav Kapelyushnikov, Andrei Kuznetsov, Olga Kuznetsova, (2011),"Diversity within capitalism: the Russian labour market model", Employee Relations, Vol. 33(4): 395- 412

http://dx.doi.org/10.1108/01425451111142693 


\section{Diversity within Capitalism: The Russian Labour Market Model}

Rostislav Kapelyushnikov, Andrei Kuznetsov*, Olga Kuznetsova

Dr. Rostislav Kapelyushnikov - Chief Researcher, Institute of World Economy and International Relations, The Russian Academy of Sciences, Moscow.

Address: IMEMO, Profsoyushaya Ulitsa, 23, Moscow GSP-7, Russia. E-mail: rostisk@ rol.ru

Dr. Andrei Kuznetsov - Professor of International Corporate Social Responsibility, Lancashire Business School.

Address: Lancashire Business School, University of Central Lancashire, Greenbank Building, Preston, PR1 2HE, UK. E-mail: akuznetsov@uclan.ac.uk

Dr. Olga Kuznetsova - Senior Lecturer in International Business, Manchester Metropolitan University Business School.

Address: MMUBS, Aytoun Building, Aytoun Street, Manchester, M1 3GH, UK. E-mail: o.kuznetsova@mmu.ac.uk

* Corresponding author 


\section{Diversity within Capitalism: The Russian Labour Market Model}

\section{Abstract}

Purpose - To investigate labour market practices in a transition economy in relation to broader institutional configurations

Design/methodology/approach - Through a review of relevant literature and the analysis of statistical data the paper reveals some specific factors influencing labour market practices in a transition economy

Findings - We establish a link between inefficient enforcement and the emergence of compensating institutional arrangements on the one side and the unusually broad implementation of flexible working time and flexible pay on the other as a crucial factor that made the stabilisation of employment in Russia possible.

Originality/value - We reveal how a formal regulatory system, which on the face of it is similar to what is a norm in the majority of European countries, may coexist with a distinctive labour market model and explore issues of relevance to academics, researching in the field, policy-makers, human resource managers, employers and employees.

Keywords: Employment, Enforcement, Institutions, Russian Labour Market Article type: Research paper

\section{Introduction}

Although originally dealing with firms and their role in the process of economic adjustment (Hall and Soskice, 2001), with time the Varieties of Capitalism (VoC) concept expanded to include the meso and macro levels as well. Following this trend the current paper focuses on the labour market and labour relations system, which literature identifies among the institutional features that distinguish the different types of capitalism (Kong, 2006). If the employers choose to rely on skilled and experienced employees producing complex quality 
products as their business strategy, such strategy fosters a whole set of consequences in terms of training provisions, decision-making responsibilities, autonomy, task quality, teamwork, employee motivation, etc. This creates skills specificity at company and industry levels that helps to establish long-term relations between employers and employees, increasing job security and employee well-being, and eventually translating into a more stable rate of employment. Literature usually holds these features to be more typical of the so-called 'coordinated market economies' (Gallie, 2007; Harcourt et al., 2007), in which firms generally have greater strategic interaction with local stakeholders and other actors such as suppliers and trade unions.

In this paper we seek to probe the labour market in Russia within the framework of the VoC approach. Its noticeable attribute is that employment has always been relatively stable despite a sequence of economic shocks that it had to withstand. Surprisingly, correlation between changes in GDP and employment dynamics has been weak, which distinguishes Russia from the transition economies of Central and Eastern Europe where the employment dynamics have been following changes in economic growth more intimately. May this be interpreted as a sign that the institutional system in the country is moving towards a coordinated type? In search for answers we look at employment conditions in modern Russia.

There is a substantial body of publications dealing with the labour market in Russia (notably Boeri and Terrell, 2002; Commander and Tolstopyatenko, 1997; World Bank, 2003), however they do not embrace the institutional setup as their main focus, while the current paper - does. Our approach is influenced by the view expressed in literature that entrepreneurial actors are constrained by institutions, but at the same time perceive institutions as resources and are looking for ways to make institutions work for them (Hall and Thelen, 2009; Streeck, 2004). As Streeck and Thelen (2005, p.19) explain, “...institutions are the object of ongoing skirmishing as actors try to achieve advantage by interpreting or 
redirecting institutions in pursuit of their goals, or by subverting or circumventing rules that clash with their interests." In line with this thinking we scrutinise the enforcement regime in Russia as we seek to explicate why the formal regulatory system, which on the face of it is so similar to what is a norm in the majority of European countries, may coexist with a labour market model so distinctive in many respects. To preview our findings, we find a link between inefficient enforcement and the emergence of compensating institutional arrangements on the one side, and the unusually broad implementation of flexible working time and flexible pay as the two crucial factors that made the stabilization of employment possible on the other. The example of Russia, therefore, confirms the thesis that in the modern world the pressures for convergence are counteracted by idiosyncratic national institutional arrangements which are the outcome of specific historical pathways, interlinked in a complex whole and persistent over time (Whitley, 1999). At the same time our analysis emphasises the limitations of an approach based on a bi-polar model (CME versus LME) understood too literally. Institutional systems, in transition economies in particular, prove to be difficult to classify as they continue to develop in response to economic and social pressures. Accordingly, in the final part of the paper we look at how the Russian model of the labour market has reacted to the current economic crisis.

\section{VoC, Institutions and Enforcement}

Within the rather wide spectrum of comparative capitalisms literature Hall and Soskice's (2001) VoC paradigm has established itself as one of the most influential conceptual frameworks (Deeg and Jackson, 2007). VoC theory makes two important contributions that are particularly relevant to this research. First, it puts social institutions in the centre of comparative analysis, maintaining that institutional variation across nations is economically significant because institutions are critical in determining the quality of the relationships the 
firm is able to establish internally (with own employees), and externally (with suppliers, clients, stakeholders, trade unions, business associations and governments) (Hall and Soskice, 2001, p.6). Appropriate institutions provide security of property rights, stimulate entrepreneurship, foster integration in the world economy, maintain macroeconomic stability, but, as VoC theory suggests, each one of these ends can be achieved in a number of different ways. Rodrik (2007) and Kogut et al (2004) write about the possibility of functional equivalence across several alternative combinations of institutions. This insight is related to the second important contribution - the idea of institutional complementarity. It is crucially important in explaining why countries exhibit distinct, historically determined national paths of development that tie together a number of elements (such as the industrial relations, financial, corporate governance and vocational training systems) in a coherent fashion (Fioretos, 2001).

An institution is a stable, substantive characteristic of socially-constructed states of a subeconomy which constrains agent's action choices through the convergent expectations it generates, while enabling them to economise on information processing, provided that there can be another such constraint for the same class of environments (Aoki, 1998). It is important to note that together with formal and informal rules institutions include their enforcement characteristics (North, 1991). The regulatory process is more than just setting laws and sanctions that guide the behaviour of firms and individuals. It also involves the enforcement of rules which can work through formal or informal methods (Scott, 2001). The balance between the two is normally determined by historical and cultural reasons. In response to a change in circumstances this balance may shift either way. However, this does not mean that if, for example, formal enforcement is replaced by informal enforcement in some areas this would not affect the implementation of the rules involved. Accordingly, 
institutions that appear to be very similar may play a very different role in different societies (Rodrik, 2008).

LMEs are normally perceived as open, thus making institutions more amenable to different management styles and coordination strategies as their liberal, deregulated market provides a wider margin for manoeuvre for its participants. By contrast, CMEs are characterised by a greater embeddedness of national institutions and demand greater conformity from its

participants. However 'comparative analysis of economic systems relies on ideal types of socio-economic organization, that are rarely, if ever, manifested as a totality in any one empirical situation' (Whitley, 2007, p.25). The Russian model of the labour market presents itself as an intriguing mix of CME and LME features: it appears to be governed by very strict formal regulations that are slow to change, but at the same time demonstrates remarkable flexibility and resilience to shocks. What makes the Russian case even more interesting is that as far as employee relations are concerned it is distinctive from other Central and Eastern European countries with which it shares the experience of post-communist transition.

\section{The Russian model of the labour market}

By the labour market model we imply a set of interrelated functional and institutional characteristics that determine the development path of the national labour relations and distinguish them from the setups existing in other countries. Every such model reflects the interaction between the participants of the labour market and how they react to shocks to the system caused by changes in supply and demand, the local and international business environment, etc. 
When market reforms started in Russia in the early 1990s, the reformers were under great pressure from international financial organizations (Kuznetsov and Kuznetsova, 2003) promoting the type of institutional reforms that were heavily biased towards the best-practice orthodoxy. This was done on the assumption that it was possible to determine a unique set of appropriate institutional arrangements ex ante and that convergence towards those arrangements was inherently desirable (Rodrik, 2008). As far as Russia is concerned, the results have been mixed, which is not surprising. Whilst it is possible to try and import conceptual and statutory underpinnings of the market mechanism from the West, it is not possible to recreate the circumstances under which they have emerged. Attempts to transfer best practices are likely to create immediate and long-term problems related to adaptation and interpretation of utilisable concepts. ${ }^{1}$ Institutional elements that were set in place 'from above' during the first years of reforms were not the product of an evolutionary process prioritising efficiency, but rather the implementation of a certain political agenda. In the labour market these elements were soon found coexisting with the relics of the previous economic system and also in competition with some new elements emerging out of the everyday practice of employee relations as they were evolving in the national economy. The conflict between the norms and rules imposed by the state and the motivation of the economic agents established itself as a determining factor of the development of the Russian institutional environment (Kuznetsov and Kuznetsova, 2003). This conflict is a reflection of some extreme pressures to which the institutional system in the country has found itself exposed in the course of transition to the market.

The Russian model of the labour market is the evidence of the enormity of this pressure. The circumstances of employment were forced to change in a most radical way within a very

\footnotetext{
${ }^{1}$ Often attempts to import best practices create disastrous results. Thus, according to Dolgopyatova (2004), the drive to comply with international standards has produced in Russia up to 1,500 laws and regulations related to corporate governance alone.
} 
short period of time as the apparent shortage of labour endemic to the centrally planned economy was replaced by a massive labour surplus. And yet ostensibly the 'marketisation' of labour relations has never produced such dramatic and painful results as the liberalization of prices or mass privatization, allowing some researchers to start talking about 'the Russian way' of labour market adaptation already in the early stages of reforms (Layard and Richter, 1995). In a schematic form the algorithm of the functioning of the Russian labour market is presented by Figure 1 that shows the trajectories of GDP and employment in the country in 1991-2007. One feature stands out: employment in the country was fluctuating within quite narrow margins and demonstrated robust resistance to both positive and negative economic shocks. Thus between 1991 and 1998, the most dramatic period of post-communist transition, employment in Russia shrunk by $13.5 \%$ against the background of almost the $40 \%$ decrease of GDP. In other words, each percentage point of output contraction was accompanied by only approximately $0.35 \%$ of employment reduction. The peculiarity of this stability becomes particularly prominent when Russia is compared with other transition economies in Europe: there in the majority of cases a clear correlation between employment and changes in economic growth were in evidence (Gimpelson and Lippoldt, 2001). This relative stability of the Russian labour market is even more surprising considering that the duration and the depth of the overall reform-induced economic crisis in Russia has been much more sizable than in many post-communist countries of Central and Eastern Europe (CEE) (Figure 2).

Therefore, although Russia's labour relations were essentially going through the same transformative processes as in the majority of CEE countries, the consequences were markedly different. In CEE the start of market reforms triggered a sharp increase in open unemployment. Almost immediately it reached $10 \%$ more or less everywhere and in some countries came close to $15-20 \%$. In Russia the unemployment curve showed no steep peaks 
reflecting either explosive labour shedding or intensive recruitment. Only six years after the inception of 'shock therapy' general unemployment calculated according to the ILO methodology exceeded the $10 \%$ barrier, reaching its maximum of $13.3 \%$ in 1998 .

\section{The causes of nonconformity}

What are the reasons for this apparent employment stability in the Russian labour market? A number of stereotypical explanations emerged in the early 1990s. One often cited reason was the supposed inherent paternalism of Russian employers (Brown, 1996; Clarke, 1995; Iankova, 2008). This claim was probably true for the earliest period of transition, but it had lost its validity in consequent years as the majority of firms were put in the hands of the teams of managers who arrived after privatization (Kuznetsov et al., 2008) and therefore had no previous history of relations with the work force. Another popular conjecture has been to link the performance of the labour market to the alleged low labour mobility inherited by modern Russia from the central planning days (Brown, 1993; Commander and Tolstopyatenko, 1997). It seemed only natural to predict that Russian workers should have been afraid of a free labour market and therefore willing to hold on to their old jobs at any cost. This enticing hypothesis has been disproved by reality: Russian workers have shown far greater readiness to change jobs than employees anywhere else in CEE (Kapelioushnikov, 1999). In Russia the worker turnover rate calculated as the sum of the accession rate and the separation rate was oscillating between $43 \%$ and $62 \%$ for the economy overall and $45-65 \%$ for the industry (Figure 3). Paradoxically, in the majority of cases the employment was terminated at the initiative of the employees: $65-74 \%$ of all employees who left their jobs did this of their own accord (Figure 3). Even if we assume that some of quits were in fact latent dismissals, the proportion is still high. By contrast, at the initial stage of market reforms in 
Poland, the ratio between 'voluntary' and 'involuntary' discharges was 1:7, and in Romania, as high as 1:60 (Commander and Coricelli, 1995).

The idiosyncrasies of the Russian labour market must be the manifestations of some fundamental qualities. In our opinion they are the prevalence of flexible working time and flexible pay. The relationship between flexible working conditions and employment is well researched (Besley and Burgess, 2002; Boeri et al., 2003; Botero, 2003; Cazes and Nesporova, 2003). The flexibility of working hours and pay makes it possible to offset pressures on the labour market without recourse to a drastic readjustment of employment: in lean times instead of making some workers redundant the employer may reduce the cost of operation (the usual reason for laying off the labour force) by shortening the working hours or diminishing the rate of compensation. Similarly, in a period of economic growth the ability to increase working hours and pay may boost output and productivity to an extent required by the market demand, thus reducing the need to hire more workers.

Flexible working hours and pay are not the prerogatives of the Russian model of the labour market. What distinguishes Russia is the persistence, depth and scale of these phenomena and their institutional embeddedness. The situation with wages provides a good example.

\section{Flexible pay}

The volatility of the wage in Russia has been remarkable. According to official statistics, between 1991 and 1998 wages had plummeted almost 300\% in real terms. They started to grow again in 2000 at the spectacular rate of $10-20 \%$ per year. As a result in the period preceding the current economic crisis they have grown by more than $300 \%$. In Russia the flexibility of wages is the consequence of a number of factors. First, it is the absence of 
compulsory indexation. Second, a substantial share of the wage (25-40\%) is traditionally made of bonuses and other incentive payments over which the management has considerable discretion. Third, such an extreme form of manipulating with wages has been available to Russian managers as delaying, sometimes for months, the payment of wages. This is probably the most unusual feature of the Russian system of wage payments. In essence this is a peculiar form of an involuntary interest-free loan provided by the employees to the firm for which they work on conditions decided by the management of the firm. Finally, a distinctive resource of wage flexibility in Russia has been the practice of underhand or 'shadow' salaries. Employers either disguise wages under other forms of remuneration (interest on bank deposits, insurance payments, etc.), or pay them in cash on the basis of informal agreements with employees. Whereas in 1993, 'shadow' wages amounted to $20 \%$ of the official wages, in 1996-1998, this proportion had increased to 45-46\%. According to Rosstat, the national statistical agency, even in the current period undeclared payments are common and add nearly $50 \%$ to the official average wage (Figure 4 ).

In the periods when the economic situation deteriorates all these mechanisms - the inflationary devaluation of real wages, cutting down of the incentive payments, wage arrears and manipulation with 'gray' payments - provide for a speedy decline of the cost of labour which allows firms to retain the workers who they would have been forced to release if the wage regulations had been more stringent. As a result the Russian labour market was able to respond to changes in demand by adjusting workers' remuneration rather than employment.

The labour relations system that emerged in Russia allowed the labour market to absorb many shocks, but it had a downside - it has made employment restructuring slow and inefficient. First, because employment contracts were poorly enforced employees had little incentives to 
invest in specific human capital. Second, the avoidance of formal rules allowed inefficient firms to stay in business and retain labour force that could have been used elsewhere more productively. Third, the continuation of 'obsolete' jobs was an obstacle to the creation of 'modern' jobs. Together these factors have slowed down the growth of productivity in the country.

\section{Flexible work}

The peculiarities of labour relations discussed in the previous sections the employee relations literature categorises as 'nonstandard work arrangements' (other terms used are 'alternative work arrangements' and 'nontraditional employment relations'; see Kalleberg, 2000 for a detailed literature review). These are employment relations that depart from standard work arrangements in which it is generally expected that work is done full-time on the basis of a formal contract, would continue indefinitely, and is performed at the employer's place of business under the employer's direction. Nonstandard work arrangements as a feature of a labour market are neither new nor they can be found in Russia alone. Such forms of nonstandard work arrangements as, for example, part-time work, temporary help agency and contract company employment, short-term and contingent work, and independent contracting have become rather common in developed market economies. Nonstandard work arrangements in Russia have particularities that in our opinion make them distinctive. They are the pervasiveness of nonstandard arrangements, the tendency for these arrangements to exist on the borderline between the legal and 'shadow' economy and the prevalence of 'low status' arrangements.

To appreciate the role of nonstandard work arrangements in Russia it is necessary to put things into perspective: for generations in the centrally planned economy only standard work 
arrangements were a norm. These days according to estimates the share of 'standard' workers has fallen to 60-65\% (Gimpelson and Kapelyushnikov, 2005). Literature makes a distinction between 'good' and 'bad' forms of nonstandard arrangements (Kahne, 1992; Tilly, 1996). 'Good' forms are a part of an integration strategy used to retain valued workers or to allow them to use their potential with maximum efficiency (for example, work from home); these forms do not reflect negatively on the status of the job. 'Bad' forms represent a marginalization strategy that provides employers with a source of cheap labour; they are associated with low paid low status jobs. Nonstandard arrangements in Russia gravitate to the latter category. They usually have as their target the minimization of the cost of labour to the employer. The most popular arrangements are shortened working hours and administrative unpaid leaves, wage arrears and 'gray' salaries, non-monetary payments (payments in kind). Employers also often expect their work force to obtain secondary employment or to hold multiple jobs, or to produce goods and services in their households to support their income. As a result the gap between what employees are paid and the income they need to survive may be huge. There were periods when as much as a quarter of Russian industrial workers were made to work part-time or were given non-voluntary holidays. From $10 \%$ to $15 \%$ of all employed have to have more than one job; one of every seven employees was involved in 'working on the side'. During the most difficult years of the reforms the majority of salaried workers experienced delays, often substantial, of the payment of wages: for example, in 1996-2000 the stock of wage arrears on average was approximately equivalent to two monthly wage bills (Lehmann and Wadsworth, 2002; see also Earle and Sabirianova, 2002). A striking feature is that a large proportion of population is involved in subsistence agriculture: during the peak of the farming season about $40 \%$ of adult population is involved in work on private allotments. 


\section{Employee relations and the institutional environment}

In Russia nonstandard arrangements are distinguished by their persistence, scale and ubiquity. As time went by these non-standard forms began to be accepted as routine everyday practices and soon transformed into a norm of employee relations. In other words, they have become institutionalised. Due to its focus on path dependency and complementarity the VoC framework is instrumental in identifying the factors which, in our opinion, explain the speed with which this transformation has happened.

The first group of factors is historical. The Soviet production system with its emphasis on technological determinism was leaving very little space for the human factor. In the Soviet period the centralization of the economic system and political control over economic affairs meant that genuine worker involvement in firm management and wage determination was very limited (Feldman, 2006). The implications were at least twofold. First, this contributed to the attitude of inertia and resignation towards changes in the conditions of employment introduced by the management. Second, it created the readiness and the moral acceptance of taking advantage of loopholes in official rules. As a result already during the era of central planning the enforcement of labour policies was flawed: as Alec Nove (1991, p.89) once noted, wage regulations if they interfered with plan fulfilment were, 'whenever possible, [to] be evaded by management in collusion with the workforce'. To compensate for rigidities of the official system, certain structural, cultural and ideological norms came into existence to provide an informal hierarchy cementing together 'work collectives,' suppliers and buyers, creditors and debtors (Kuznetsov, 1994). 
Historical influence is also evident in the role that trade unions (TUs) play in the Russian labour relations. In the Soviet period the TUs were a segment of state bureaucracy and the party apparatus and not the independent force representing the interests of employees and protecting their rights. Therefore the Soviet TUs were not the sovereign stakeholders that the VoC literature puts, together with employer organizations, in the centre of analysis due to their important coordination functions (Hall and Soskice, 2001). When the new Constitution of the Russian Federation came into force in 1993, TUs were formally separated from the state. At the same time they were deprived of their main assets and their rights and tasks in the sphere of social insurance and labour protection were limited to the functions of public control. The traditional TUs representing about $80 \%$ of all employees chose the route of 'social partnership' with the state: this was in essence an agreement according to which the TUs took upon themselves to uphold social stability in exchange for a part in the running of social policy. As a result in the 1990s despite the radical change in the social and economic situation TUs were mostly inactive (Chen and Sil, 2006). The position of modern Russian TUs in the institutional system therefore is essentially very similar to the position of Soviet TUs: on the paper they have many rights, but in reality they have subordinated themselves to the state and their influence and prestige are low (Chetvernina, 2009). Managers, for their part, often ignore or dilute 'general pacts' negotiated between TUs and employer associations (Zaslavsky, 2001).

The situation with TUs is symptomatic of the state of affairs with the labour legislation in general. There is a big gap between the letter of the law and its implementation. The implications cannot be exaggerated. Whilst employee relations were going through the period of extreme transformation, the employment legislation was remaining almost unchanged. With some amendments the Soviet Labour Code of 1971 was operational until 2002. Despite 
all the tweaking it proved to be hopelessly inadequate as soon as the market reforms started. On paper the legal norms remained very stringent but their real strength was nominal. The flexibility of the provision of labour as required by the market mechanism was achieved by ignoring the norms and replacing them with informal institutions.

The new Code, adopted in 2002, was the product of a political compromise (Gimpelson and Kapelyushnikov, 2005). It is not surprising therefore that in it norms reflecting the realities of the market economy coexist with the relics of the Soviet era. Most importantly, all the administrative and financial barriers that made it almost impossible for the employer to lay off an employee have been preserved. Overall the employment legislation in Russia remains extremely cumbersome (on top of the Labour Code of Russia there are more than 100 other laws and regulations) and restrictive. According to the evaluations of authoritative international bodies, from the legal point of view the Russian labour market is one of the most regulated and controlled. Thus the World Bank's 'rigidity of employment index' available on www.doingbusiness.com is 38 for Russia and 26 for OECD countries (higher values indicate more rigid regulations). The 'difficulty of redundancy index' is 40 for Russia and 22.6 for OECD countries.

It is widely accepted in literature that more restrictive employment legislation constrains diversity and dynamism in the labour market and thus reduces employment opportunities (OECD, 2006; Slinger, 2001). This implies that the Russian labour market maintains its high level of adaptability not because of the regulatory system but in spite of it. This is only possible if the regulatory superstructure lacks the powers of control and enforcement. 
Indeed law implementation has been extremely flawed in Russia (ILO, 1997; Feige, 1997; Vishnevskaya and Kapelyushnikov, 2007). This created a vacuum of formal regulations which was soon filled in with a plethora of informal and surrogate 'rules of the game' as described in previous sections. This has changed the whole hierarchy of stimuli motivating the participants of the labour market. The nonstandard forms of employee relations have one thing in common: when enacted in most cases this involved either using the loopholes in the existing legislation or contradicting the law. As a result both workers and their employers were willing to accept that their relations had become mostly informalised as implicit rules and unwritten agreement prevailed over contract provisions and other formal obligations. As Shevtsova (2003, p.16) aptly put it, 'the Russian system did not need fixed rules of the game; it needed fixers'.

\section{Russian model and economic crisis}

The contraction of demand for oil and gas in the world market following the US financial crisis of 2008 undermined Russia's economic growth: in the first half of 2009 it fell by $10.4 \%$ in comparison to the same period in 2008 ; industrial output contracted by $14.8 \%$. The 2008 2009 economic crisis has been a major test for the existing model of the labour market. Will this model survive or will it be replaced by a new one, which will be closer to other European labour markets? As we tried to demonstrate, the main functional feature of the model established in Russia has been the low flexibility of employment. This characteristic can be used to reveal probable changes in the elasticity of the model. Thus, evidence that the fall of output is not accompanied by a correspondent decrease in employment may be judged as a sign that the existing model remains operational. Conversely, low employment elasticity to output may be seen as an indication that a new model is taking over. 
We are only able to apply our 'economic' check to the early period of the crisis for which some data are already available. The initial reaction of Russian firms has not been radically different from the pattern that was observed in the 1990s. Although there was the shedding of labour on a scale that had not been seen since 1994, the increase in unemployment was nowhere as intensive as the severity of the economic crisis suggested. According to official estimates, in the first half of 2009 GDP fell by more than $10 \%$, but general employment only by $2.5-2.7 \%$. As before Russian firms were keen to avoid mass redundancies. Instead they have chosen the 'soft' strategy of adjusting their labour requirements. This time, however, the adjustment was mostly centred on a wide scale reintroduction of nonstandard work arrangements leading to reduced working hours: in the fourth quarter of 2008 the number of employees who were forced into part-time work increased ten times comparing to the same period of 2007 (Kapelyushnikov, 2009). We estimate that as a result of these measures the employers have achieved savings that otherwise would have required an increase in unemployment of $7-8 \%$.

By contrast, manipulations with wages have not been as common as previous experience made possible to expect. The fall of the real wages has been rather shallow at less than $10 \%$. This is almost negligible comparing to disastrous drops in real wages that were a feature of economic shocks in the previous decade. This can be attributed at least in part to institutional reasons: wage regulations have been made more effective as this time the state that has taken a very firm position towards those enterprises that were delaying the pay.

Overall it can be argued that the adjustment to the crisis in the sphere of employment has been unproblematic: decline in real wage and the rate of employment has been limited, 
however the share of involuntary part-time employment has increased to the level of the late 1990s.

Therefore, despite similarities the current situation is somewhat different comparing to the 1990s. Then the main factor of the relative stability of the rate of employment was the inflationary decrease in the real cost of labour. This time the state has been implementing a steady anti-inflationary policy, making this option unavailable to the employers. The state has made its presence more noticeable in the realm of employment regulations as well. In many cases penalties for infringing the law have been made more severe and effective. For example, the legislator specifically targeted wage $\operatorname{arrears}^{2}$ : now it is a criminal offense to deliberately delay the payment of wages. The freedom of the employer to send the workers on administrative unpaid leaves has been curtailed too.

We can see that the institutional setup related to the employee relations demonstrates continuity as well as the signs of erosion. It is too early to judge the extent of emergent changes and if they are going to persist. However the likely directions of the changes is quite apparent: first, it is taking out the slack that exists in the regulatory system because of poor enforcement; second, it is reducing the cost of employment associated with the stringent implementation of the Labour Code.

\section{Conclusions}

The institutional core of the current model of labour relations in Russia is a combination of very stringent formal rules embodied in the Labour Code and the great variety of informal arrangements that make it feasible to 'soften' these rules or circumvent them altogether. This

\footnotetext{
${ }^{2}$ There may be a good reason for federal policymakers to fear the accumulation of wage arrears as regions with higher wage arrears tended to have higher votes for the political opposition in the 1993 parliamentary election and lower votes for the incumbent in the 1996 presidential election (Gimpelson et al., 2000).
} 
structure helps to absorb external shocks by means of shortening working hours and other measures that minimise the cost of labour. This is a flexible system, but this flexibility is not the product of a deliberate effort of the legislator as in a liberal market economy. The formal rules are numerous and stringent but, unlike a coordinated market economy, their impact is mostly marginal. The flexibility comes from the willingness and ability of both employers and employees to curtail their exposure to formal rules and rely on informal arrangements instead.

Superficially the Russian labour market seems to fit the CME model with its weak numerical flexibility but strong functional flexibility as firms seek to compensate their inability to lay off workers with a variety of redeployment tactics. However, the CME archetype allocates a crucial role to the state as the enforcer of agreements and the provider of the infrastructure and incentives for co-operation, the elements which are missing in Russia. At the same time, as in LME, the Russian system is characterised by the absence of strong corporatist institutions or arrangements allowing organized interests participate directly in the formulation of government policy. Another feature of LME, the priority of short-term labour market logic over the objective of long-term firm or national competitiveness, is also present. The institutional mechanism that makes this symbiosis of CME and LME archetypes possible is the combination of poor enforcement of formal rules and the ubiquity of informal arrangements. In Russia the line between formal and informal sectors in the economy is blurred to such an extent that the behaviour of large corporations and state owned enterprises is often indistinguishable from that of the operators of the 'grey' economy.

The model that emerged in the 1990s has helped to ease the impact on employment of the hardships and shocks that accompanied transition to the market. At the same time its 
contribution was not entirely positive. To begin with, it has undermined the status of one of the central institutions in any market economy - the contract. Without properly enforced contracts both employers and employees were forced to shorten the time horizon when making their decisions about jobs. This had negative consequences for the specific human capital in the country and the information transparency of the labour market. Overall the existing mechanism puts the burden of supporting stable employment on the employees themselves who pay for this stability by giving up a share of their real wages.

The countries of Central and Eastern Europe show noticeable differences in respect of institutional arrangements characteristic of the labour market as they appear to be moving towards a rather inflexible EU model. To an extent, however, all European transition economies face difficulties with the enforcement of employment regulations, but not on the scale that exists in Russia (Gimpelson and Kapelyushnikov, 2004; Eamets and Matso, 2004). The future of the Russian model therefore will very much depend on how the state of affairs with enforcement will be resolved. 
Figure 1.

GDP growth and employment in Russia 1991-2007 (1991 = 100\% $)$

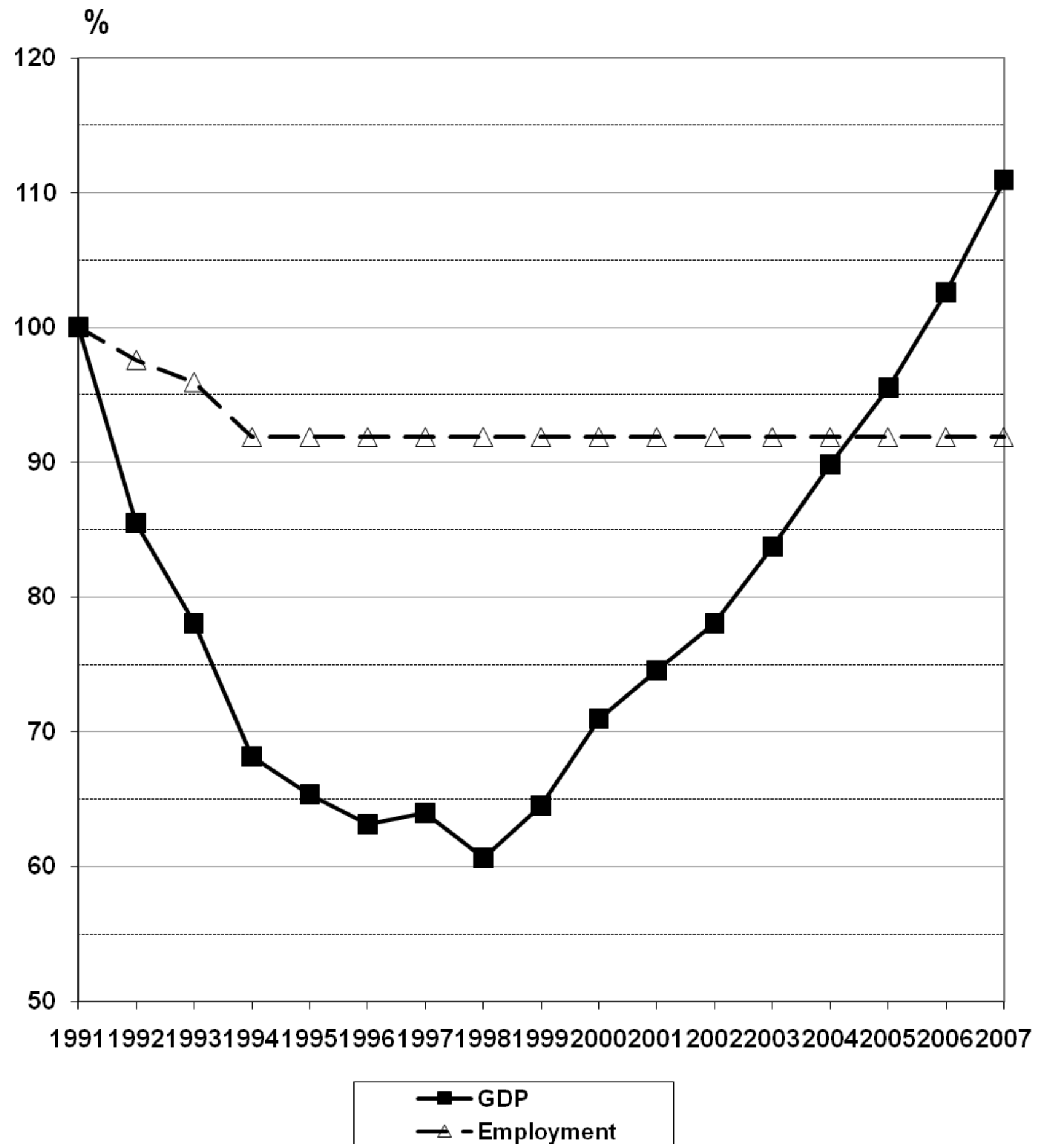

Source: Rosstat 
Figure 2.

The rates of unemployment in post-communist countries, 1997-2007 (\%)

a. General unemployment

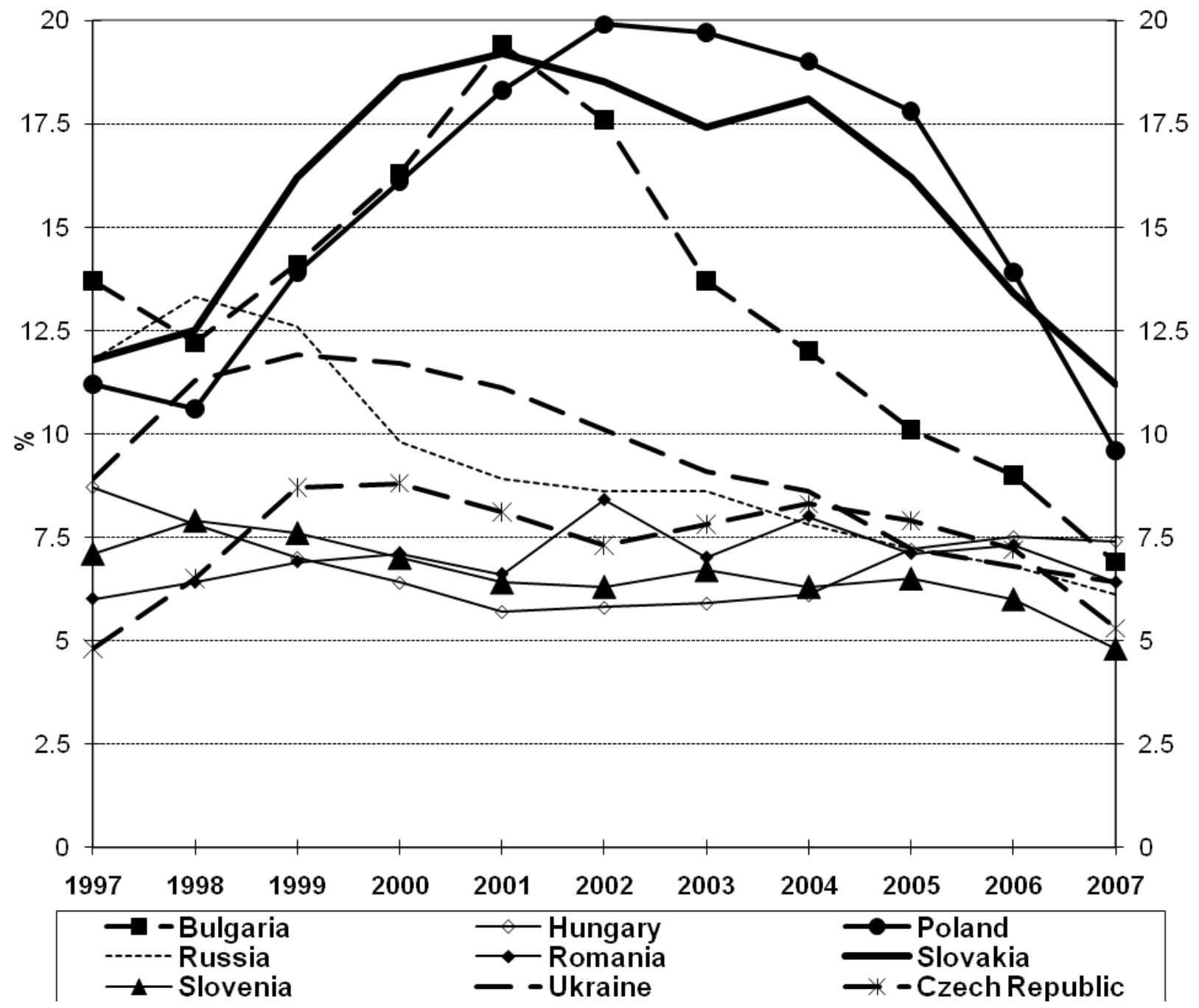

Source: Rosstat 
b. Registered unemployment

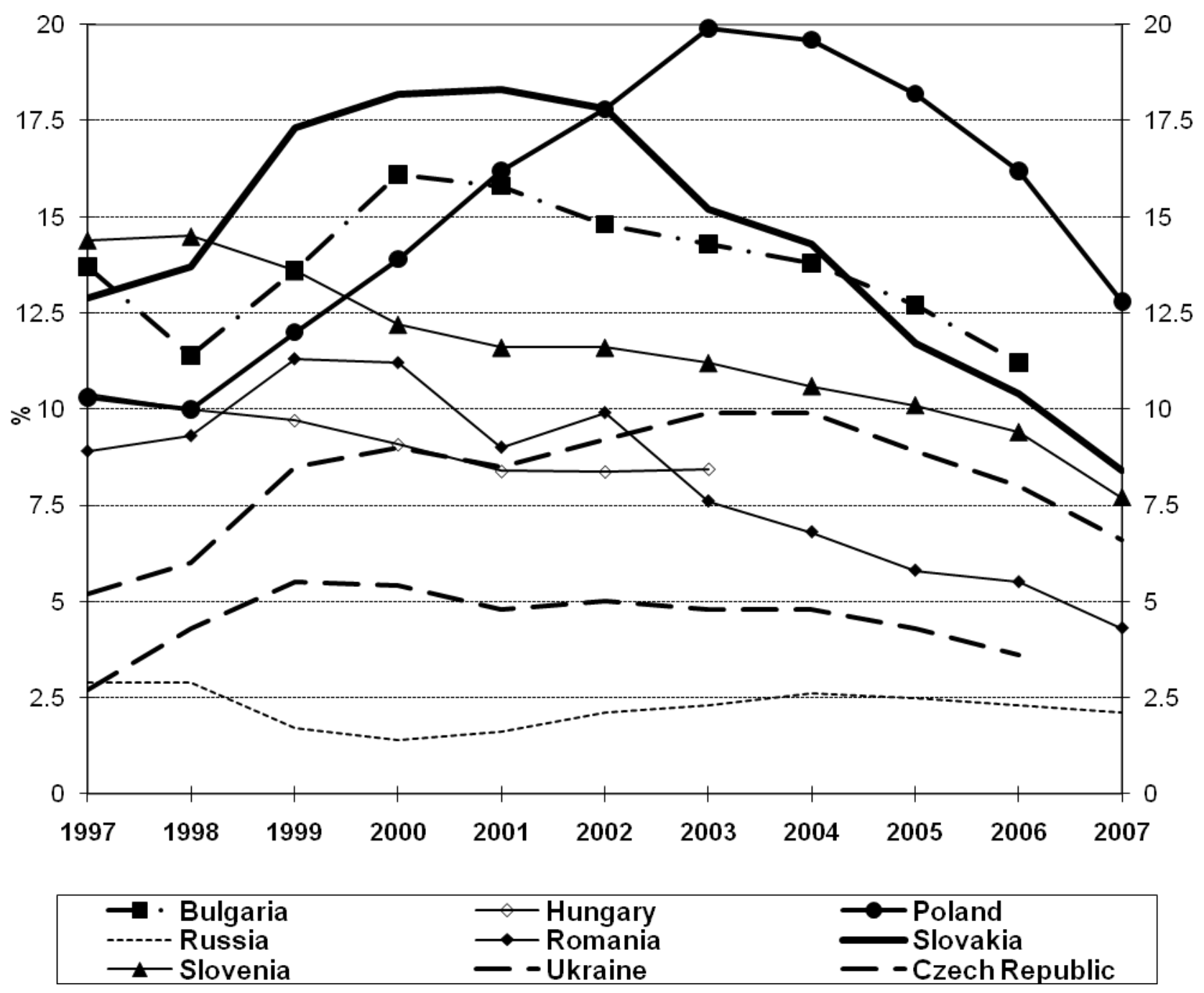

Source: Rosstat 
Figure 3.

The dynamics of employment in Russia 1992-2008 (\%).

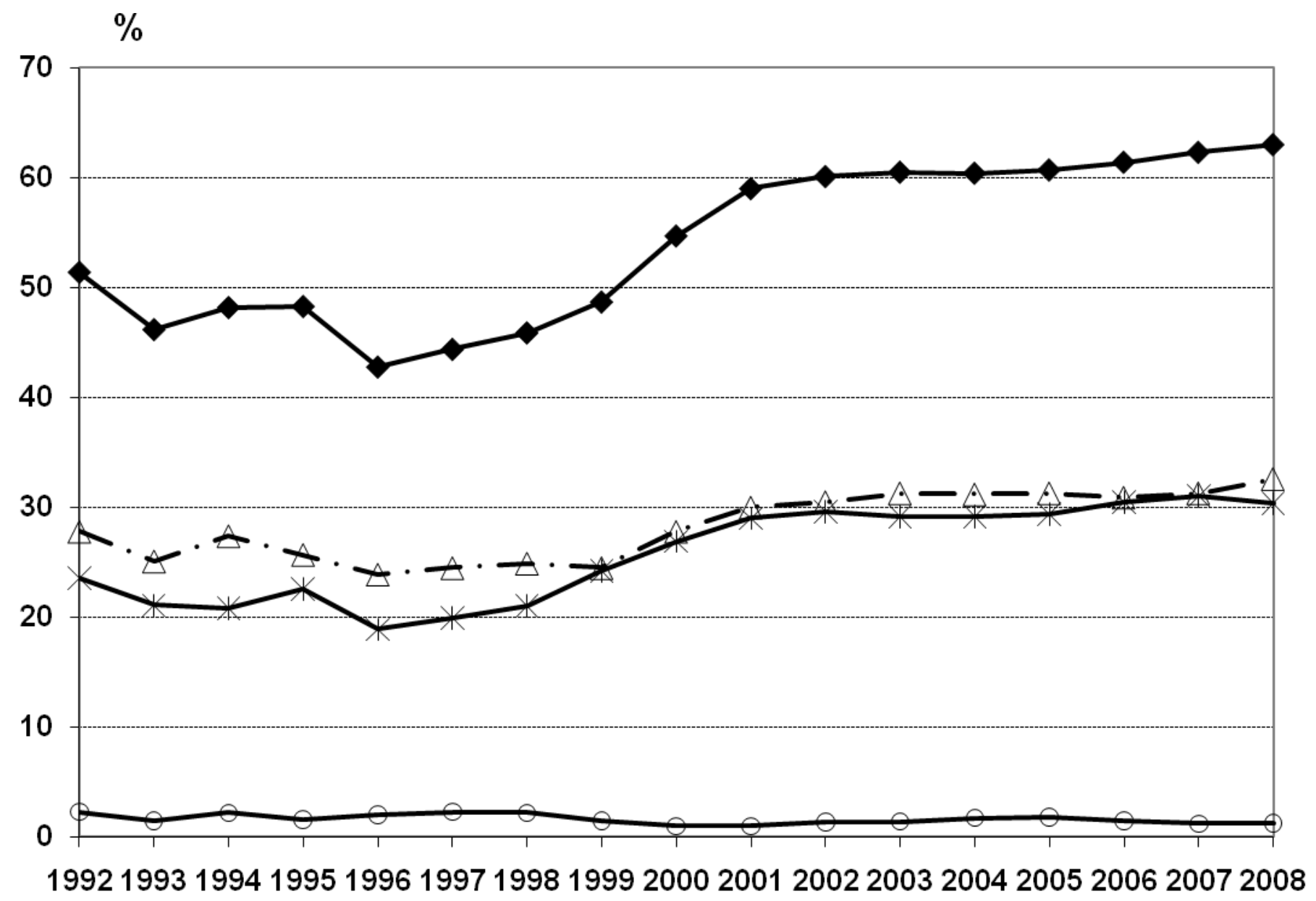

Source: Rosstat 
Figure 4 .

Average wage dynamics 1997-2006 (Rubles, thousands).

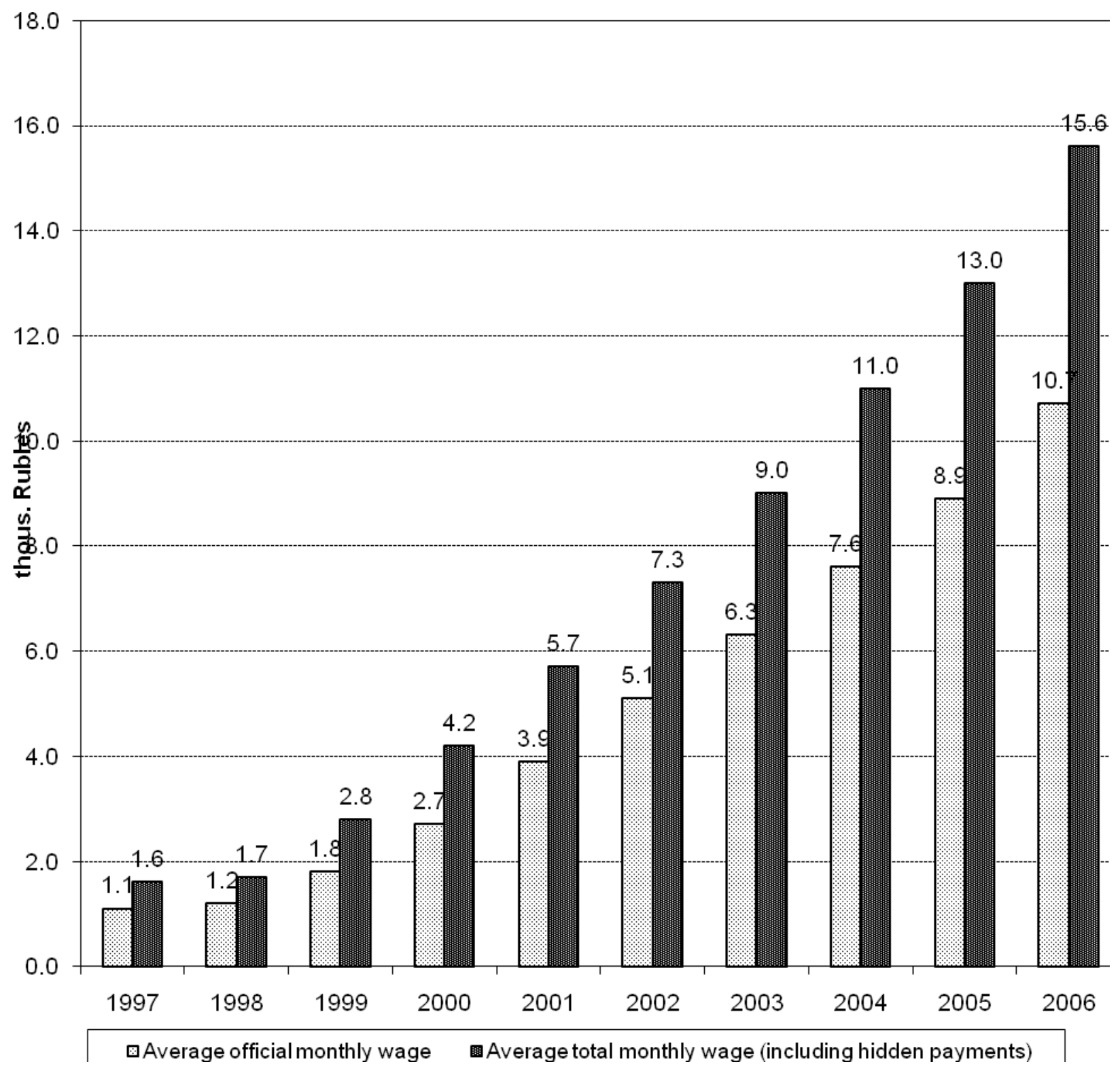

Source: Rosstat 


\section{Bibliography}

Aoki, M. (1998), "The subjective game form and institutional evolution as punctuated equilibrium". Paper presented at The International Society for New Institutional Economics 2nd Annual Conference, September 17-19, Paris.

Besley, T. and Burgess, R. (2002), "Can labor regulation hinder economic performance? Evidence from India”. Quarterly Journal of Economics, Vol. 117 No.4, pp.1415-51.

Boeri, T. and Terrell, K. (2002), "Institutional determinants of labor reallocation in transition", Journal of Economic Perspectives, Vol. 16 No.1, pp.51-76.

Boeri, T., Ignacio Conde-Ruiz, J., Galasso, V. (2003), "Protecting against labour market risk: employment protection or unemployment benefits?" CEPR Discussion Paper No. 3990. Available at SSRN: http://ssrn.com/abstract=443067.

Botero, H., Djankov, S., La Porta, R., Lopez-de-Silanes, F., Shleifer, A. (2004), "The regulation of labor", Quarterly Journal of Economics, Vol.119 No.4, pp.1339-82.

Brown, A. (1993), “A note on industrial adjustment and regional labor markets in Russia”, Comparative Economic Studies, Vol.35 No.4, pp.147-57.

Brown, J.D. (1996), "Excess labour and managerial shortage: findings from a survey in St. Petersburg", Europe-Asia Studies, Vol. 48 No.5, pp.811-35.

Cazes, S. and Nesporova, A. (2003), Labour markets in transition: Balancing Flexibility and Security in Central and Eastern Europe. Geneva: ILO.

Chen, C. and Sil, R. (2006), "Communist legacies, post communist transformations, and the fate of organized labor in Russia and China", Studies in Comparative International Development, Vol. 4 No.2, pp. 62-87. 
Chetvernina, T. (2009), “Trade Unions in transitional Russia - peculiarities, current status and new challenges". Working Paper No. 16, Russian Research Center, Institute of Economic Research Hitotsubashi University Tokyo.

Clarke, S. (1995), "Formal and informal relations in Soviet industrial production" in Clarke, S. (Ed.), Management and Industry in Russia, Cambridge: Edward Elgar, pp.1-28.

Commander, S., and Coricelli, F. (Eds) (1995), Unemployment, Restructuring and the Labour Market in Eastern Europe and Russia. The World Bank, Washington, DC.

Commander, S., and Tolstopyatenko, A. (1997), "Unemployment, restructuring and the pace of transition", in: Zecchini, S. (Ed.), Lessons from the Economic Transition. Central and Eastern Europe in the 1990s, Kluwer Academic Publishers, Dordrech, pp.331-50.

Deeg, R., and Jackson, G. (2007), "The state of the art: towards a more dynamic theory of capitalist variety", Socio-Economic Review, Vol.5 No.1, pp.149-79.

Eamets, R. and Matso, J. (2004), "Labour market regulation and employment protection legislation in the Baltic States", Discussion Paper No. 1147, Institute for the Study of Labour (IZA), Bonn.

Earle, J.S. and Sabirianova, K.Z. (2002), "How late to pay? Understanding wage arrears in Russia", Journal of Labor Economics, Vol.20 No.3, pp.661-707.

Feige, E.L. (1997), "Underground activity and institutional change: productive, protective and predatory behaviour in transition economies", in Nelson, J. M., Tilly, C., Walker, L. (Eds), Transforming Post-Communist Political Economies, National Academy Press, Washington, D.C, pp.21-33.

Feldman, M. (2006), "Emerging varieties of capitalism in transition countries: industrial relations and wage bargaining in Estonia and Slovenia", Comparative Political Studies, Vol.39 No.7, pp.829-54. 
Fioretos, O. (2001), “The domestic sources of multilateral preferences: varieties of capitalism in the European community", in Hall, P. A. and Soskice D. (Eds), Varieties of Capitalism, Oxford University Press, New York, NY, pp. 213-44.

Gallie D. (2007), "Production regimes and the quality of employment in Europe", Annual Review of Sociology, Vol.33, pp.85-104.

Gimpelson, V., and Lippoldt, D. (2001), The Russian Labour Market: between Transition and Turmoil, Rowman \& Littlefield Publishers, New York, NY.

Gimpelson, V., Treisman, D., Monusova, G. (2000), "Public employment and redistributive politics: evidence from Russia's regions", Discussion Paper No. 16, Institute for the Study of Labour (IZA), Bonn.

Gimpelson, V., and Kapelyushnikov, R. (2004), "Trudovye otnosheniya" in Obzor ekonomicheskoi politiki v Rossii za 2003, Bureau of Economic Analysis, Moscow.

Gimpelson, V., and Kapelyushnikov, R. (Eds) (2005), Nestandartnye formy zaniatosti v Rossii, Moscow State University-Higher School of Economics Publishing House, Moscow.

Gimpelson, V., and Kapelyushnikov R. (Eds) (2007), Zarabotnayia plata v Rossii: evolutsia $i$ differentsiatsia. Moscow State University-Higher School of Economics Publishing House, Moscow.

Granick, D. (1960), The Red Executive, Anchor Books, New-York, NY.

Hall, P.A., and Soskice, D. (2001), Varieties of Capitalism. The Institutional Foundations of Comparative Advantage, CUP: Cambridge.

Hall, P.A., and Thelen, K. (2009), "Institutional change in varieties of capitalism", SocioEconomic Review, Vol.7 No.1, pp. 7-34. 
Harcourt, M., Wood, J., Roper, I. (2007), “The importance of legislated employment protection for worker commitment in coordinated market economies", Journal of Economic Issues, Vol. 41 No. 4, pp.961-80.

ILO (1997), World Labour Report: Industrial Relations, Democracy, and Social Stability, 1997-98. International Labour Organization, Washington DC.

Iankova, E.A. (2008), "From corporate paternalism to corporate social responsibility in postcommunist Europe", The Journal of Corporate Citizenship, Issue 29, pp.75-89.

Kahne, H. (1992), "Part-time work: a hope and a peril”, in Warme, B., Lundy, K., Lundy, L. (Eds.), Working Part Time: Risks and Opportunities.: Praeger, Westport, CT, pp. 295-309.

Kalleberg, A. L. (2000), "Nonstandard employment relations: part-time, temporary and contract work", Annual Review of Sociology, Vol.26 No.3, pp.341-65.

Kapeliouchnikov, R. (1999), “Russia’s Labour Market: Adjustment without Restructuring”. Paper presented at the NATO Colloquium "Economic Developments and Reforms in Cooperation Partner Countries: the Link between Economics, Security and Stability”, Nov 35, NATO, Brussels, Belgium.

Kapelyushnikov, R. (2009), Konets rossiiskoi modeli rynka truda, Liberal Mission Fund., Moscow.

Kogut, B., MacDuffie, J. P., Ragin, C.C. (2004), "Prototypes and strategy: assigning causal credit using fuzzy sets”, European Management Review, Vol.1 No.2, pp.114-31.

Kong, T.Y. (2006), "Globalization and labour market reform: patterns of response in Northeast Asia”, British Journal of Political Science, Vol.36 No.2, pp.359-83.

Kuznetsov, A. and Kuznetsova, O. (2003), "Institutions, business and the state in Russia", Europe-Asia Studies, Vol.55 No.6, pp.907-22. 
Kuznetsov, A., Kapelyushnikov, R. and Dyomina, N. (2008), "The performance of closely held firms in Russia: evidence from firm-level data", The European Journal of Finance, Vol.14 No.4, pp.337-58.

Layard, R. and Richter, A. (1995), "Labour market adjustment - the Russian way", in Aslund, A. (Ed.), Russian Economic Reform at Risk, Pinter, London.

Lehmann, H. and Wadsworth, J. (2002), "Wage arrears and the distribution of earnings in Russia", Discussion Paper 2002/02, Centre for Economic Reform and Transformation, School of Management, Heriot-Watt University, Edinburgh, UK.

Margo, R. (1998), "Labor and labor markets in the 1930s", in Wheeler, M., (Ed.), The Economics of the Great Depression, W.E. Upjohn Institute for Employment Research, Kalamazoo, MI, USA.

North, D. (1991), “Institutions”, The Journal of Economic Perspectives, Vol.5 No.1, pp. 97-112.

Nove, A. (1991), The Economics of Feasible Socialism Revisited, HarperCollins Academic, London.

OECD (2006), "Social implications of policies aimed at raising employment", OECD Employment Outlook, OECD, Paris.

Rodrik, D. (2007), One Economics, Many Recipes: Globalization, Institutions, and Economic Growth, Princeton University Press, Princeton, NJ, USA.

Rodrik, D. (2008), "Second-best institutions", American Economic Review, Vol. 98 No.2, pp.100-4.

Scott, W. (2001), Institutions and Organizations, Sage, Thousand Oaks, CA, USA.

Shevtsova, L. (2003), Putin's Russia, Carnegie Endowment for International Peace, Washington D.C, USA. 
Slinger, T. (2001), "Some labour market implications of employment legislation", Labour Market Trends, Vol.109 No.1. Available on http://findarticles.com/p/articles/mi_qa3999/is_200109/ai_n8962569/

Streeck, W. (2004), "Taking uncertainty seriously: complementarity as a moving target" in Workshop Proceedings of the Osterreichische Nationalbank, Vol.1 No.1, pp.101-15. Available: http://www.oenb.at/en/img/taking_uncertainty_seriously_wb1_tcm16-15992.pdf

Streeck, W., and Thelen, K. (Eds) (2005), Beyond Continuity: Institutional Change in Advanced Political Economies, Oxford University Press, Oxford.

Tilly, C. (1996), Half a Job: Bad and Good Part-time Jobs in a Changing Labor Market. Temple University Press, Philadelphia, PA, USA.

Thelen, K. (2004), How Institutions Evolve. The Political Economy of Skills in Germany, Britain, the United States, and Japan. Cambridge University Press, New York, NY, USA.

Vishnevskaya, N., and Kapelyushnikov, R. (2007), “Infrorsment trudovogo zakonodastel'stva v Rossii", Working paper No.3, Working paper series "Problems of Labour Market", Moscow State University-Higher School of Economics, Moscow.

Whitley, R. (1999), Divergent capitalisms: the social structuring and change of business systems, Oxford University Press, Oxford:

Whitley, R. (2007), Business Systems and Organizational Capabilities: The Institutional Structuring of Competitive Competencies, Oxford University Press, Oxford.

World Bank (2003), The Russian labor market: moving from crisis to recovery, The International Bank for Reconstruction and Development/The World Bank, Washington DC, USA.

Yakovlev, A. (2004), "Evolution of corporate governance in Russia: government policy vs real incentives of economic agents", Post-Communist Economies, Vol.16 No.4, pp.387-403. 
Zaslavsky, V. (2001), 'The Russian working class in times of transition', in Bonneil, V. and Breslauer, G. (Eds), Russia in the New Century, Westview Press. Boulder, CO, pp.201-30. 